\title{
Technical, financial, economic and environmental pre-feasibility study of geothermal power plants by RETScreen - Ecuador's case study
}

\author{
Diego Moya ${ }^{1,2}$, Juan Paredes ${ }^{1}$, Prasad Kaparaju ${ }^{3}$ \\ ${ }^{1}$ Carrera de Ingeniería Mecánica, Facultad de Ingeniería Civil y Mecánica, Universidad Técnica \\ de Ambato, Avd. Los Chasquis y Rio Payamino s/n, Ambato, Ecuador \\ ${ }^{2}$ Department of Chemical Engineering, Imperial College London, London, SW7 2AZ, UK \\ ${ }^{3}$ Griffith School of Engineering, Griffith University, Nathan Campus, 4111 Queensland, Australia
}

\section{Corresponding author}

E-mail addresses: diego.moyapinta@griffithuni.edu.au, da.moya@uta.edu.ec (D Moya), p.kaparaju@griffith.edu.au (P Kaparaju)

\begin{abstract}
In this paper, technical, financial, economic and environmental analysis of geothermal power plant developments in the Ecuadorian context was analysed by RETScreen International Geothermal Project Model. Three different scenarios were considered for the analyses. Scenario I and II considered incentives of 132.1 USD/MWh for electricity generation and grants of 3 million USD. For Scenario III, geothermal project with an electricity export price of 49.3 USD/MWh considered. Scenario III was further divided into IIIA and IIIB case studies. Scenario IIIA considered a 3 million USD grant while Scenario IIIB considered an income of 8.9 USD/MWh for selling heat in direct applications. Modelling results showed that binary power cycle was the most suitable geothermal technology to produce electricity along with aquaculture and greenhouse heating for direct use applications in all scenarios. Financial analyses showed that the debt payment would be 5.36 million USD/year under in Scenario I and III. The correspindig values for Scenario II was 7.06 million USD/year. Net Present Value was positive for all studied scenarios except for Scenario IIIA. The equity paybacks were 3.2, 3.7, 16 and 5.6 years for Scenario I, Scenario II, Scenario IIIA and Scenario IIIB, respectively. Overall, Scenario II was identified as the most feasible project due to positive NPV with short payback period. Interestingly, Scenario IIIB could become financially attractive by selling heat for direct applications. Direct applications, public incentives and clean funding mechanisms are essential for the success of geothermal energy projects in the Ecuadorian context. The total initial investment for a $22 \mathrm{MW}$ geothermal power plant was 114.3 million USD (at 2017 costs). Economic analysis showed an annual savings of 24.3 million USD by avoiding fossil fuel electricity generation. More than $184,000 \mathrm{tCO}_{2}$ eq. could be avoided annually. Thus, the greenhouse emissions avoided on the use of geothermal energy would bring out environmental benefits and improve the socio-economic benefits in communities.
\end{abstract}

Keywords: Geothermal energy, technical analysis, economic analysis, financial analysis, direct uses, geothermal power plant, RETScreen modelling 


\section{Highlights}

The total geothermal power generation potential in Ecuador is estimated at $3000 \mathrm{MWe}$ with approximately $133 \mathrm{MWe}$ of power generated in the three most advanced geothermal prospects.

Power generation, direct applications, public incentives and clean funding mechanisms are essential for the success of geothermal energy projects in Ecuador.

Approximately 162,000 tonnes of $\mathrm{CO}_{2}$ eq. per year greenhouse gas emissions can be avoided.

Annually, we can save 486,500 barrels of crude oil imports, which is equivalent to 24.3 million USD per year. 
Abbreviations

\begin{tabular}{|ll|}
\hline FAM & Financial Analysis model \\
SRAM & Sensitivity and Risk Analysis Models \\
NPV & Net Present Value \\
PUGR-E & Plan for the Utilization of Geothermal Resources in Ecuador \\
UNFCCC & United Nations Framework Convention on Climate Change \\
IGA & International Geothermal Association \\
WB & World Bank \\
MEER & Ministry of Renewable Energy and Electricity \\
SENPLADES & National Secretary of Planning and Development \\
CELEC-EP & Ecuadorian Electricity Corporation \\
INER & National Institute of Renewable Energy of Ecuador \\
CONELEC & National Electricity Council \\
SENESCYT & Secretariat for Higher Education, Science, Technology and Innovation \\
NASA & National Aeronautics and Space Administration \\
MW & Megawatt \\
UNEP & United Nations Environment Programme \\
kW & Kilowatt \\
kWh & Kilowatt-hour \\
kg/s & Kilogram per second \\
kg/h & Kilogram per hour \\
${ }^{\circ} \mathrm{C}$ & Centigrade degree \\
$\% \%$ & Percentage \\
bar & Bar \\
kPa & Kilopascal \\
USD & United State Dollars \\
Mtoe & Millions tons of oil equivalent \\
GHG & Greenhouse gas emissions \\
GJ & Gigajoules \\
tCO2 & Tonnes of carbon dioxide \\
Ctv & Cents of dollar \\
T\&D & Transmission and distribution \\
\hline
\end{tabular}




\section{Introduction}

The United Nations Framework Convention on Climate Change (UNFCCC) considered greenhouse gas emissions reduction targets in the member states to limit the increase in the global mean temperature and the inevitable effects on global warming and climate change [1]. More recently, the Paris Agreement ambitiously has addressed to limit global warming to no more than $1.5^{\circ} \mathrm{C}$ above pre-industrial levels [2]. The use of renewable energy sources to produce electricity plays an important role in the reduction of greenhouse gases [3-6]. By the end of 2017, global energy supply will reach 16,000 million tons of oil equivalent (Mtoe) with renewable energy resources accounting for $15 \%$ (2,400 Mtoe) [7]. It is estimated that developed and developing countries might require 23,885 Mtoe by 2050 [8]. Although the accuracy of estimating the global renewable energy potential is arguable, the unused global potential of renewable energy resources is estimated to be 179,135 Mtoe with geothermal energy accounting for 119,423 Mtoe [8,9]. Thus, development of geothermal energy should be considered as a sustainable alternative to deal with future energy security challenges. In this regard, Ecuador has committed to increase the share of renewable energy through the restructuration of its energy matrix $[10,11]$ to contribute to the UNFCCC and Paris Agreement targets [12, 13].

Techno-economic analysis of geothermal projects allows developers, investors and policy makers to have a complete view of the financial pre-feasibility of these kind of highly risky investment decisions [14-16]. Geothermal stakeholders have greatly agreed in the eight development phases of a geothermal power project [16, 17]. Figure 1 shows the critical success factors along the eight development phases to meet in geothermal project developments. Different approaches have been established to study the technical and financial viability of renewables in general $[18,19]$ and geothermal in particular [20-23].

In the case of geothermal projects analysis, there are studies focused in specific phases of the development rather than in throughout the project [24]. Several researchers have previously estimated the cost of well drilling [21,25-26], technical and financial aspects of geothermal power plants [27-30], operation and maintenance costs or annual costs of a geothermal power plant [1831] and costs of electricity generation in a geothermal power plant [19-32-34]. Other researcher have evaluated the feasibility of developing hybrid power plants consisting of geothermal and solar $[32,35,36]$ to produce fuels i.e., hydrogen $[18,22,23,34,37,38]$. 


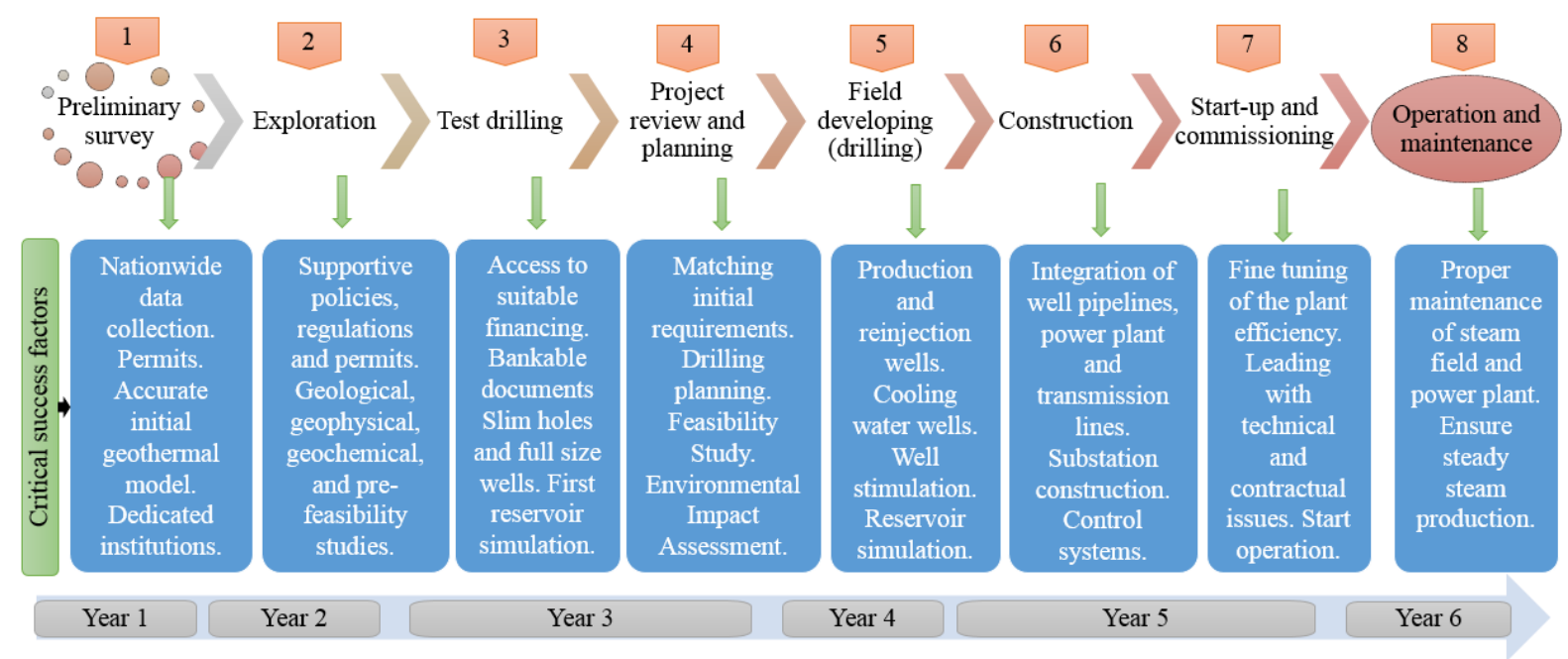

Figure 1: Critical Success Factors in the development phase of a geothermal project. Achieving the economic viability of a geothermal project requires rigorous control of costs of each development phase $[16,39,40]$.

Pre-feasibility studies of geothermal projects helps us to estimate initial and annual costs, saving and production of energy, and focus development prior construction [41, 42]. Due to the complexity of these studies, different models were developed [41, 43, 44]. These modelling tools are classified as pre-feasibility, sizing, simulation and open architecture research tools [44]. For the purpose of this research, RETScreen modelling tool was used. This RETScreen International Clean Energy Project Analysis Software was developed by the Ministry of Natural Resources of Canada in collaboration with National Aeronautics and Space Administration (NASA), United Nations Environment Programme (UNEP), industry partners, and academia [45, 46]. It is a free software that can be used to evaluate energy production, life-cycle costs and greenhouse gas emission reductions for various proposed renewable energy technologies [42, 44, 46]. RETScreen offers a proven methodology focused on the pre-feasibility and feasibility studies, rather than developing a custom-developed methodology $[47,48]$. This tool has been extensively used to carry out pre-feasibility studies of solar projects [48-56], wind projects [57-60], hydropower projects [61, 62], and a geothermal study [63].

Ecuador is committed to increase the share of renewable energy through the restructuration of its energy matrix [10,11,64], including geothermal energy [12, 13]. Diversification of the Ecuadorian energy matrix represents an important milestone in the development of its economy throughout the process of changing its energy and productivity matrix. According to the Ministry of Renewable Energy and Electricity (MEER), it is expected that the share of the electricity should be approximately $85 \%$ from hydroelectric power plants, $10 \%$ from fossil-fuel-fired thermal power plants and 5\% from other renewables such as wind and biomass by the end of 2017 [65]. The 
National Plan of Living Well of Ecuador, developed by the National Secretary of Planning and Development (SENPLADES), aims to make changes to the energy matrix and productivity matrix during the next decade [66]. These changes are supported by the New 2008 National Political Constitution and directed by the Plan of Electrification 2025 [67]. In order to change the productivity matrix, the SENPLADES has identified fourteen productivity sectors and five strategic industries [68], which will affect the structure of the energy matrix by increasing the demand for electric energy in the country. This rise of electricity demand would increase the consumption of fossil fuels due to its demand on fossil-fuel-fired thermal power plants. However, the new energy gap, as a result of the change of the productivity matrix, should be filled with electricity produced in renewable power plants such as geothermal power, considering that there are no current geothermal plants in the country $[69,70]$. Therefore, geothermal power generation could be a viable option to diversify the electric energy matrix in the country.

The analysis of the technical and economic potential for geothermal development is paramount. Only five of the forty odd active volcanoes in Ecuador were studied due to their potential to generate electricity [70]. Most of these investigations are currently in the exploration stage [69-72]. Furthermore, there are other geothermal prospects to be explored to determine their potential for direct use in industry and agriculture. The Ecuadorian Electricity Corporation (CELEC-EP), a public company, is leading the geothermal development for electricity generation in the country along with cooperation from the scientific and technical support of the National Institute of Renewable Energy of Ecuador (INER), under the MEER [69, 70]. The production of electric energy and direct use of thermal energy from geothermal resources in the Ecuadorian context is an option to diversify its Energy Matrix and to support the energy challenges that the change of the Productivity Matrix may produce in the coming years. Geothermal energy harvesting might not only reduce the consumption of fossil fuels, reducing the environmental electricity production impact, but could also create new opportunities of research, employment and positive economic impacts in Ecuadorian society. In Ecuador, $3000 \mathrm{MW}_{\mathrm{e}}$ of total geothermal potential with approximately $133 \mathrm{MW}_{\mathrm{e}}$ in the three most advanced geothermal prospects has been estimated [69]. However, despite its high geothermal potential, Ecuador is currently using the geothermal resources for restricted direct heat applications: swimming pools, medicinal mineral hot springs, balneology, spas and bathing resorts [70, 71, 73].

The aim of the study is to identify the most economically viable and feasible technology to harvest energy from geothermal resources identified by CELEC-EP and INER in Ecuador. At first, the technical feasibility of the utilisation of geothermal resources to produce electricity, and to harvest direct energy use in the Ecuadorian industry was conducted. Later, financial analysis of the costs, policies and funding to the geothermal configurations identified in the technical feasibility analysis was carried out along with the evaluation of the economic impact of the 
development of the studied geothermal energy systems in the Ecuadorian economy. Finally, emission analysis was also presented.

\section{Methodology:}

Data was collected from reports published by CELEC, INER-MEER, IGA (International Geothermal Association), WB (World Bank) and PUGR-E (Plan for the Utilization of Geothermal Resources in Ecuador - unpublished government document).

The RETScreen modelling tool was used for the feasibility analysis [44]. This model evaluates the energy production of different clean and renewable technologies including life-cycle costs and greenhouse gas emissions (GHG) emission reductions [44, 46, 48]. Furthermore, it provides standardised and integrated financial analysis, sensitivity and risk analysis in order to determine the financial viability and risk of the project $[46,48,50]$.

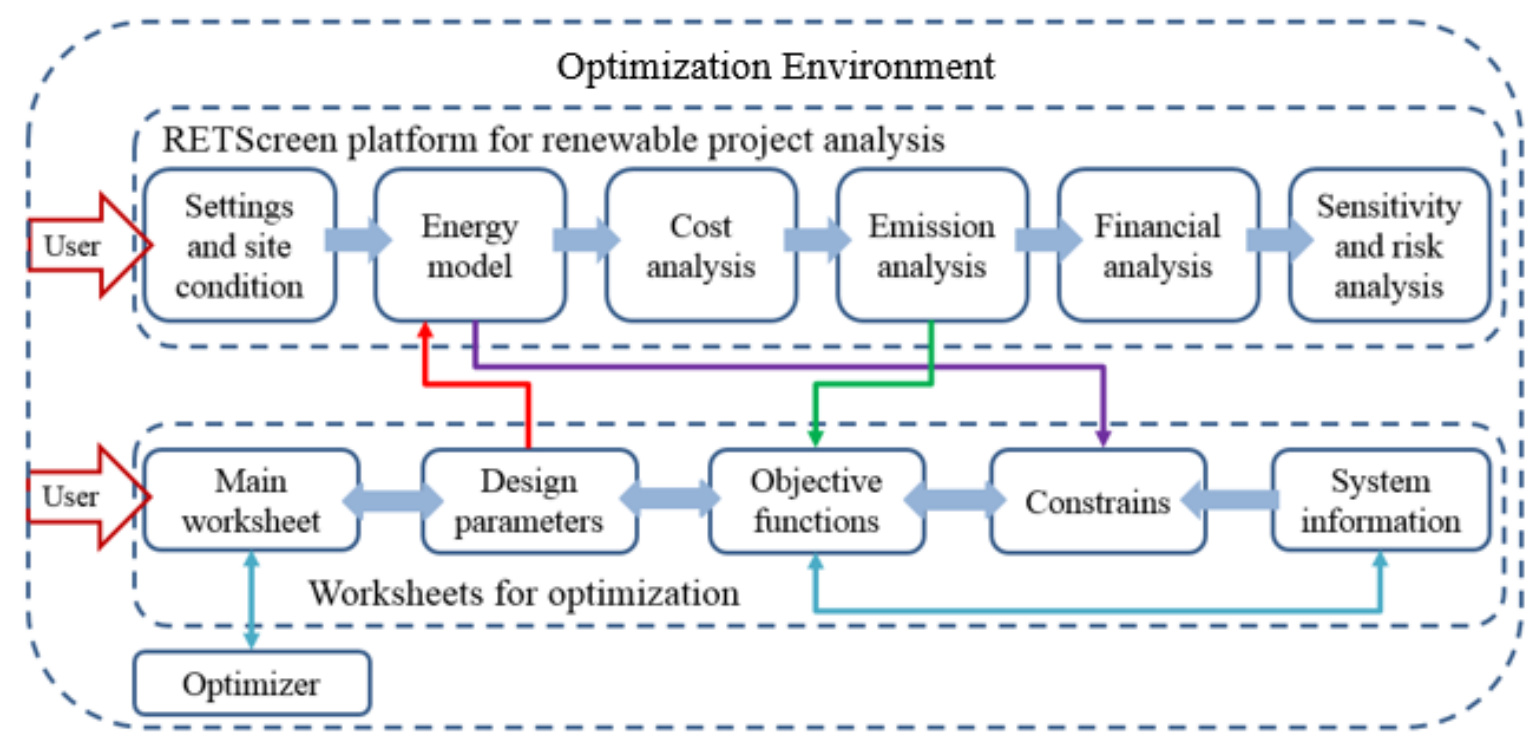

Figure 2: RETScreen model flow chart showing the five-step standard analysis and design parameters [46]. RETScreen modelling includes the Energy Model, the Greenhouse Gas Emission Reduction Analysis Model, the Financial Analysis model (FAM), and the Sensitivity and Risk Analysis Models (SRAM). The FAM includes debt payments, pre-tax and after-tax cash flows, asset depreciation, income tax and financial feasibility indicators, while the SRAM includes the Monte Carlo simulation, impact graph, median and confidence interval, and the risk analysis model validation.

Figure 2 illustrates the five steps required to complete the analysis: The Energy Model, the Greenhouse Gas Emission Reduction Analysis Model, the Financial Analysis model (FAM), and the Sensitivity and Risk Analysis Models (SRAM) [74]. The FAM includes debt payments, pretax and after-tax cash flows, asset depreciation, income tax and financial feasibility indicators, 
while the SRAM includes the Monte Carlo simulation, impact graph, median and confidence interval, and the risk analysis model validation [45].

\subsection{Statement of assumptions}

For financial analyses, some assumptions were established based on the literature data [7577]. This study found that the costs have increased by approximately $50 \%$ during the period 2009 2016. Therefore, the assumptions for the total investment costs were based on this growth rate. The following sections present the procedure for technical, financial and economic data analyses.

\subsubsection{Technical data}

In RETScreen model, technical analysis was defined by the energy model. In the technical analysis, electricity energy matrix, and how geothermal power generation and direct use technologies would be relevant to the goal of changing the Ecuadorian energy and productivity matrices were evaluated. Based on the recent and previous studies published by CELEC-EP, the potential geothermal prospects for electricity generation and direct applications have been conceptualised with their technical feasibility to be developed. Finally, the sub-problems related to the state of the electricity sector framework of Ecuador to develop geothermal projects were also considered in the analysis.

Table 1 presents the data required to proceed with the technical analysis using RETScreen. Based on the literature, parasitic load of $10 \%$ and transmission losses of $2 \%$ were assumed in this study [77, 78]. Consequently, the effective full load power capacity for a $22 \mathrm{MW}$ geothermal power plant was estimated at $19.36 \mathrm{MW}$. 
Table 1: Data used to calculate the Power capacity and Grid exported electricity of the proposed configuration for the Energy Model by RETScreen software.

\begin{tabular}{lrlr}
\hline Technical item & Quantity & Unit & Source \\
\hline Installed capacity & Up to 81 & $\mathrm{MW}$ & {$[79]$} \\
of geothermal power & 81,000 & $\mathrm{~kW}$ & \\
Availability & 97 & $\%$ & {$[78]$} \\
Production wells & 5 & wells & {$[80,81]$} \\
Reinjection wells & 2 & wells & {$[80,81]$} \\
\multicolumn{1}{c}{ Total wells } & 7 & wells & \\
Steam flow & 65 & $\mathrm{~kg} / \mathrm{s}$ & {$[81,82]$} \\
& 234,000 & $\mathrm{~kg} / \mathrm{h}$ & \\
\multicolumn{1}{c}{5 production wells } & $1,170,000$ & $\mathrm{~kg} / \mathrm{h}$ & \\
Temperature & $210-350$ & ${ }^{\circ} \mathrm{C}$ & {$[79]$} \\
(fluid in reservoir) & & & \\
Operation pressure & 6 & $\mathrm{bar}$ & {$[82,83]$} \\
& 600 & $\mathrm{kPa}$ & \\
Steam temperature & 200 & ${ }^{\circ} \mathrm{C}$ & {$[79]$} \\
Back pressure & 3.95 & $\mathrm{bar}$ & {$[83]$} \\
& 395 & $\mathrm{kPa}$ & \\
Steam turbine efficiency & 80 & $\%$ & {$[84]$} \\
Minimum capacity & 50 & $\%$ & {$[42,45]$} \\
Electricity export rate & 132.1 & $\mathrm{USD} / \mathrm{MWh}$ & {$[85]$} \\
Parasitic loads & 10 & $\%$ & {$[77]$} \\
& 2.2 & $\mathrm{MW}$ & \\
Transmission loss & 2 & $\%$ & {$[77]$} \\
Construction time & 0.44 & $\mathrm{MW}$ & \\
Life time & 18 & $\mathrm{months}$ & {$[77]$} \\
& 15 & Years & {$[86]$} \\
\hline & 25 & Years & {$[16]$} \\
\hline
\end{tabular}

\subsubsection{Financial data}

In the financial analysis, detailed investment costs were assessed to formulate the most complete financial model for the development of geothermal energy projects. This approach will identify the limitations and opportunities for investment in geothermal power projects in the Ecuadorian context. The role of funding bodies, both public and private, current carbon and energy tax policies, and other related frameworks were also considered in this analysis. The input data required by the RETScreen Cost Analysis Model are presented in detail in Table 2. 
Table 2: Input data on investment and operating costs for the geothermal power plant in Ecuador used based on literature data and adapted to the Ecuadorian context as of December 2016 $[76,77,87]$.

\begin{tabular}{|c|c|c|}
\hline \multicolumn{3}{|c|}{ Capital costs - Initial investment } \\
\hline Exploration & $4,500,000$ & USD \\
\hline Well field development ( 7 wells: 5-production, 2 -injection) & $35,000,000$ & USD \\
\hline Plant equipment (using 1.5 scale factor) & $57,000,000$ & USD \\
\hline Permits for land use & 750,000 & USD \\
\hline Interconnection & 375,000 & USD \\
\hline Overheads profit & $11,715,000$ & USD \\
\hline Construction schedule & 18 & Months \\
\hline Interest during construction & 6 & $\%$ \\
\hline Contingencies & 6.5 & $\%$ \\
\hline \multirow{2}{*}{\multicolumn{3}{|c|}{$\begin{array}{c}\text { Total } 109,340,000 \\
\text { Operating costs - Annual costs }\end{array}$}} \\
\hline & & \\
\hline \multicolumn{3}{|l|}{ LABOR } \\
\hline Plant manager - SP10 (1x\$2308x12months) & 27,696 & USD \\
\hline Plant operators - SP3 (8x\$986x12 months) & 94,656 & USD \\
\hline Mechanic - SP3 (1x\$986x12months) & 11832 & USD \\
\hline Other labour - SP1 (1x\$817x12months) & 9804 & USD \\
\hline Total & 143,988 & USD \\
\hline
\end{tabular}

\section{PLANT}

Turbine/generator

Electric and control systems

Cooling systems

37,500 USD

Auxiliary systems

64,500 USD

Cooling water and chemicals

9,000 USD

19,500 USD

Miscellaneous and consumables*

70,500 USD

WELL FIELD

Well clean

75,000 USD

Brine chemicals

201,000 USD

Miscellaneous*

138,000 USD

75,000 USD

52,500 USD

Total

213,000

USD

*These values are included in the $\%$ of contingencies.

MAJOR OVERHAUL

\section{Major overhaul (maintenance), fees, resource costs}

Plant $(\mathrm{L}+\mathrm{M})$, every 3 years

$$
\begin{array}{rl}
1,161,000 & \mathrm{USD} / 3 \text { yrs. } \\
387,000 & \mathrm{USD} / \mathrm{yr} \\
36,000 & \mathrm{USD} / 3 \mathrm{yrs} . \\
1,125,000 & \mathrm{USD} / 3 \mathrm{yrs} . \\
75,000 & \mathrm{USD} / 2 \mathrm{yrs} \\
37,500 & \mathrm{USD} / \mathrm{yr} . \\
3,450,000 & \mathrm{USD} / 5 \mathrm{yrs} . \\
690,000 & \mathrm{USD} / \mathrm{yr}
\end{array}
$$$$
\text { Labour - L (90\$/h, 400h) }
$$

Materials, parts - $\mathrm{M}$

Well maintenance (every 2 years)

Well replacement (every 5 years)

\section{FUEL RESOURCE}

Community benefits ( $3 \%$ of total electricity sales)

$$
\begin{aligned}
229,979 & \text { USD } \\
37,500 & \text { USD } \\
9,750 & \text { USD } \\
8,400 & \text { USD } \\
\mathbf{4 0 0 , 1 2 9} & \text { USD }
\end{aligned}
$$

Make-up water 
In annual costs, the operation and maintenance of the power plant was calculated based on three individual costs: parts and labour, well field and contingencies. The parts cost was related to the parts required for the turbine-generator, the electric and control systems, the cooling system, auxiliary systems, and cooling water and chemicals. The annual labour costs were calculated at an operating labour of 11 staff: 1 plant manager, 8 plant operators, 1 mechanic and 1 labourer. These costs have been taken from the unified scale of monthly salaries from the Ministry of Labour Relations of Ecuador [87]. RETScreen financial analysis model calculates two main financial indicators: debt payment and Net Present Value (NPV). Debt payment is the sum principal portion increases with time, and the interest portion decreases with time. On the other hand, NPV is the value of all future cash flows in today's currency discounted at the proposed discounted rate [45]. A positive NPV indicates that the project is feasible in financial terms. Finally, the second set of financial indicators i.e. simple and equity payback periods are analysed [88]. Simple payback represents the length of time for the proposers to recoup their initial investment, while equity payback represents the length of time for the owner to recoup its own initial investment [45].

\subsubsection{Economic data}

RETScreen Cost Analysis Model includes costs related to development, engineering, power system and balance of systems and miscellaneous, for initial costs; and operation and maintenance, for annual costs [46]. In the economic analysis, specific micro-economic and macroeconomic variables were considered [22]. From the micro-economic point of view, the electricity market structure of Ecuador was studied in order to determine if there were any structures to support geothermal developments. In addition, the demand and supply of renewable energy and how geothermal energy could play an important role in the diversification of the Ecuadorian Energy Matrix was analysed. From the macro-economic point of view, four variables were addressed: the share of renewable energy production; and finally, employment opportunities that geothermal projects may establish was also studied.

\subsubsection{Greenhouse gas emissions data}

In the GHG analysis, a comprehensive Ecuador's energy matrix was considered by including primary energy and electricity consumptions. RETScreen Greenhouse Gas Emissions Analysis Model provides the carbon dioxide $\left(\mathrm{CO}_{2}\right)$, methane $\left(\mathrm{CH}_{4}\right)$, and nitrous oxide $\left(\mathrm{N}_{2} \mathrm{O}\right)$ emissions that can be avoided on replacing fossil fuel with renewable energy resource [45, 74]. Table 3 presents the input data on the share of each fuel type in the country's fuel mix, electricity 
generation efficiency, and the transmission and distribution (T\&D) losses $[65,89,90]$ along with GHG emission factors used for calculating GHG emissions.

Table 3: Input data for calculating the greenhouse gas emissions in the base case electricity scenario $[45,65,67,89-91]$.

\begin{tabular}{lccccccc}
\hline Fuel type & $\begin{array}{c}\text { Fuel } \\
\text { mix }\end{array}$ & $\begin{array}{c}\text { CO2 } \\
\text { emission } \\
\text { factor }\end{array}$ & $\begin{array}{c}\text { CH4 } \\
\text { emission } \\
\text { factor }\end{array}$ & $\begin{array}{c}\text { N2O } \\
\text { emission } \\
\text { factor }\end{array}$ & $\begin{array}{c}\text { Electricity } \\
\text { generation } \\
\text { efficiency }\end{array}$ & $\begin{array}{c}\text { T\&D } \\
\text { losses }\end{array}$ & $\begin{array}{c}\text { GHG } \\
\text { emission } \\
\text { factor }\end{array}$ \\
\cline { 2 - 8 } & $\%$ & $\mathrm{~kg} / \mathrm{GJ}$ & $\mathrm{kg} / \mathrm{GJ}$ & $\mathrm{kg} / \mathrm{GJ}$ & $\%$ & $\%$ & $\mathrm{tCO} / \mathrm{MWh}$ \\
Oil & 90.0 & 74.12 & 0.0029 & 0.0019 & 28.60 & 12.4 & 1.075 \\
Natural gas & 4.0 & 49.36 & 0.0036 & 0.0009 & 40.80 & 12.4 & 0.501 \\
Hydro & 4.0 & 0.00 & 0.0000 & 0.0000 & 100.00 & 12.4 & 0.000 \\
Biomass & 2.0 & 0.00 & 0.0299 & 0.0037 & 23.30 & 12.4 & 0.033 \\
& & & & & & & \\
Electricity & 100.0 & 272.05 & 0.0136 & 0.0073 & & 12.4 & 0.988 \\
mix & & & & & & & \\
\hline
\end{tabular}

\subsubsection{Scenarios}

Three likely scenarios were studied. Scenario I was based on a project life of 25 years, which is the usual term for World Bank geothermal projects [16]. Scenario II was based on a project life of 15 years, which is the usual term for the National Electricity Council, CONELEC, renewable energy projects [86]. For Scenario I and II, an incentive and grants of 3 million USD were considered, an amount already provided by the government. Scenario III does not take into account the government incentive of $132.1 \mathrm{USD} / \mathrm{MWh}$ and the project was considered as fossilfuel power plant project at $49 \mathrm{USD} / \mathrm{MWh}$ [86]. Within Scenario III, two separate cases were considered based on the availability of different financial incentives viz., other grants, direct application, GHG reduction income and Clean Energy production income. In Scenario IIIA, electricity export price at 49.3 USD/MWh and 3 million USD grant was considered. On the other hand, grants, incentives and direct applications of heat were considered in Scenario IIIB. In addition, Scenario IIIB also assumes 20 million USD government grants and an income of 8.9 $\mathrm{USD} / \mathrm{MWh}$ for the sale of heat for direct applications estimated at $115 \mathrm{MWh}$ per year. Finally, two Clean Development Mechanisms (CDM) of funding were proposed. For GHG reduction income, $7 \mathrm{USD} / \mathrm{tCO}_{2}$ avoided was assumed [92]. Similary, $0.01 \mathrm{USD} / \mathrm{kWh}$ of clean energy produced was assumed under Clean Energy production income [45], which is assumed as a likely incentive if a Geothermal Law comes into existence in the country.

\subsection{Scope and limitations}


This study does not engage with geology, geophysics and exploration studies of geothermal resources. However, CELEC-EP has provided evidence of cited studies, which support the selection of potential geothermal prospects to harvest high and low enthalpy energy for electricity generation and to use in direct applications. The specific document on which this study was based is the PUGR-E, elaborated by the MEER and provided by CELEC-EP for this study [71]. It is beyond the scope of this study to conduct laboratory experiments to support the technical analysis. The technical analysis of the penetration of geothermal energy systems in the energy and productivity matrix of Ecuador was based on a detailed and systematic review of the related scientific and academic literature of the technologies currently in use to harvest energy from geothermal resources. The study would suggest plant configurations to produce electricity and thermodynamic cycle configurations for direct use of geothermal resources. The boundaries of the financial analysis were subjected to the current financial framework of Ecuador. However, it was proposed to conduct this analysis using three scenarios. The first scenario was based on the current financial environment, which is public funding. The second was a mixed funding between public and private funds. While the third scenario was studied without any incentives but taking into account other funding sources.

A full discussion of micro- and macro-economic variables lies beyond the scope of this study. Therefore, the study focused on the economic aspects previously described in section 2.1.2 through 2.1.5. Nevertheless, the analysed economic variables should be more than adequate to predict the economic impact of the penetration of geothermal energy projects in the Ecuadorian economy.

\section{Results and discussion}

\subsection{Geothermal energy potential in Ecuador}

Figure 3 and Table 4 summarise the prospects of geothermal energy in Ecuador. According to MEER, the gross economic geothermal potential in Ecuador was estimated at $1000 \mathrm{MW}$ [90]. The PUGR-E report, on the other hand, suggested a geothermal potential up to $3000 \mathrm{MW}_{\mathrm{e}}$ taking into account only 20 active volcanoes [71] and 8000 MWe taking into account 30-40 volcanoes from the more than 40 active volcanoes in the country [70]. This data is accurate with the empirical relationship between the number of active volcanoes and the geo-thermoelectric potential proposed by Stefansson [93]. Nevertheless, the sustainable geothermal energy potential has not been estimated yet (Figure 3). There were two other different prospects discarded in this study. The Cerro Negro, Bi-National Ecuador-Colombia prospect was discarded due to the difficulties of finding data because of the two different government bodies in-charge of it. Furthermore, the Chalupas prospect was also discarded due to the current (September, 2015) 
eruption process of the Cotopaxi volcano, which is near to Chalupas increasing the risk of any development [71]. Therefore, the results presented in this study were mainly attributed to Chachimbiro, Chacana or Chalpatán (Table 4). It is significant to note that in all three cases, the project status is the same. The development has reached up to prefeasibility studies to pre-drilling stage, including geological, geochemical and geophysical surveys, conceptual models, risk assessment and location of first drilling sites [69, 70].

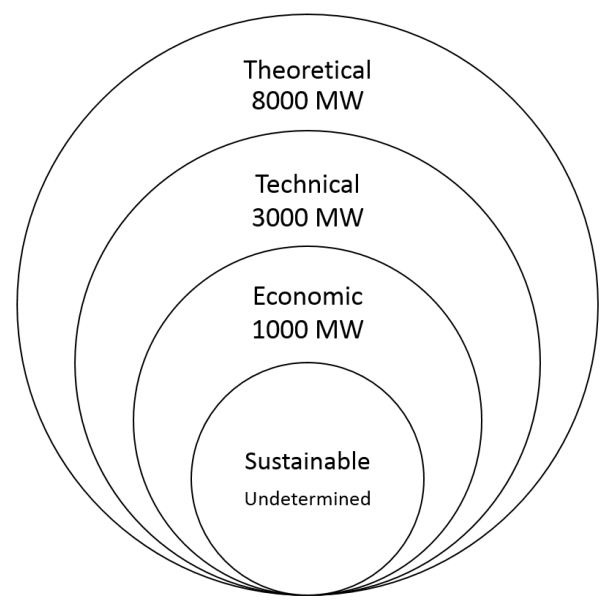

Figure 3: Geothermal potential in Ecuador. Adapted after [72]. The MEER presents a gross economic-feasibility estimation of geothermal potential at $1000 \mathrm{MW}$, the PUGR-E suggests up to 3000 MWe taking into account only 20 active volcanoes and $8000 \mathrm{MWe}$ taking into account 30-40 volcanoes from the more than 40 active volcanoes in the country $[69,70,72]$.

The Ecuadorian electric sector has been experiencing changes since 2008. The Constituent Resolution No. 15, the New 2008 National Constitution with specific articles for the energy sector and the Master Plan of Electrification are the main electricity framework to promote the change of the energy and productivity matrix of the country [65]. These policy instruments promote the use of clean energy technologies, energy efficiency management, and renewable energy [72]. In 2015 , with about $50 \%$ of the electricity matrix supported by fossil fuels (2893 MW) and $11 \%$ supported by interconnections from Colombia and Peru (635 MW), it is clear that the Ecuadorian energy sector is required to replace the fossil fuel sector with cleaner and renewable energy sources.

Table 4: The three most advanced geothermal prospects and their estimated power generation potential in Ecuador [69-72, 94, 95].

\begin{tabular}{lll}
\hline Geothermal prospect & \multicolumn{1}{c}{ Possible applications } & Estimated potential \\
\hline Chachimbiro & $\begin{array}{l}\text { Electricity generation } \\
\text { Direct Uses }\end{array}$ & $81 \mathrm{MWe}$ \\
Chacana & Electricity generation & Jamanco, 13 MWe \\
\hline
\end{tabular}




\begin{tabular}{lll}
\hline & Direct Uses & $\begin{array}{l}\text { Cachiyacu, 39 MWe } \\
\text { Oyacachi, 104 MWe }\end{array}$ \\
Chalpatán & $\begin{array}{l}\text { Not suitable for electricity production } \\
120^{\circ} \mathrm{C}, 484,000 \mathrm{GWh}\end{array}$ \\
& High potential for direct uses & \\
\hline
\end{tabular}

According to the MEER, the share of the electric energy matrix by end of 2016 should be approximately $85 \%$ from hydro power plants, $10 \%$ from fossil-fuel-fired thermal power plants and $5 \%$ from other renewables such as wind and biomass [65, 67, 72, 90]. However, the geothermal development is still in the exploration stage. There have been several studies related to the issues of hydroelectricity, where it is a major source of electricity, around water management, water storage, induced flood, and reduction of volume of rainfall [96-98]. Even though Ecuador has been fortunate to have vast hydroelectricity resources of $22,000 \mathrm{MW}_{\mathrm{e}}$ for extra production [44], geothermal electricity provides stable and reliable base-load power at a relatively low cost in comparison with other renewable sources and fossil fuels [16]. Therefore, geothermal electricity generation might be considered as an alternative to cover the $11 \%$ from fossil-fuel-fired thermal power plants expected after the introduction of the new hydroelectric power plants in 2016. Interconnections from Colombia and Peru are a great opportunity to be replaced by renewable energy generation.

\subsection{Technical analysis}

Table 5 shows the initial results of the RETScreen Energy Model Stage. This model calculates the likely power installed capacity of the proposed case geothermal power system, which would be at $22 \mathrm{MW}$. The RETScreen Energy Model also calculates the electricity exported to the grid to be 186,975 MWh (Table 5). If we assume that the major overhaul and annual maintenance might take 263 hours (equivalent to 11 days), the geothermal power availability is estimated to be $97 \%$ of the total annual availability. The electricity export rate was estimated to be 132.1 $\mathrm{USD} / \mathrm{MWh}$ as an incentive from the Ecuadorian government $[85,86]$. Assuming $10 \%$ of parasitic loads $(2.2 \mathrm{MW})$ and $2 \%$ of transmission losses $(0.44 \mathrm{MW})$, the calculated actual effective full load power capacity was about 19,360 kW (Table 5).

Table 5: Power capacity and grid exported electricity production for the proposed configuration generated from the RETScreen Energy Model.

\begin{tabular}{ll}
\hline Technology & Geothermal power \\
\hline Availability & 8,497 hours \\
Saturated temperature & $159^{\circ} \mathrm{C}$ \\
Actual steam rate & $53.17 \mathrm{Kg} / \mathrm{kWh}$ \\
Power capacity & $22,004 \mathrm{~kW}$ \\
Grid exported electricity & $186,975 \mathrm{MWh}$ \\
\hline
\end{tabular}


It is paramount to clarify that the steam flow provided to the power plant from the reservoir may vary from $50 \mathrm{~kg} / \mathrm{s}$ (slightly acceptable) to $200 \mathrm{~kg} / \mathrm{s}$ (outstanding steam flow) and may vary from location to location and geothermal reservoir, as discussed by DiPippo [81] and Shulyupin and Chermoshentseva [82]. As the drilling exploration stage does not provide the final geothermal data of the most advanced prospects, a steam flow of $65 \mathrm{~kg} / \mathrm{s}(234,000 \mathrm{~kg} / \mathrm{h})$ was assumed in this study. Based on these assumptions, five production wells are expected and produce a total steam flow of 1,170,000 kg/h. Beate and Urquizo [69] reported a range of temperatures for Chachimbiro between $110^{\circ} \mathrm{C}$ and $235^{\circ} \mathrm{C}$, for Chacana between $150^{\circ} \mathrm{C}$ and $240{ }^{\circ} \mathrm{C}$ and for Chalpatán between $74{ }^{\circ} \mathrm{C}$ and $137^{\circ} \mathrm{C}$. Likewise, a previous study by Aguilera, et al. [99] found a comparable range of temperatures for Chachimbiro between $225-235^{\circ} \mathrm{C}$. Similar data is also reported on the PUGRE [71]. However, more exploration studies including drilling are required in order to verify the actual temperatures in the geothermal reservoirs. For the purpose of this study, a steam temperature of $200{ }^{\circ} \mathrm{C}$ was assumed and is with the range of those reported in the literature [69, $71,99]$.

Based on the data provided by the PUGR-E [71], and according with DiPippo [81] and Valdimarsson [83], a binary power plant was considered as the appropriate technological solution for electricity generation in any of the most advanced geothermal prospects. In addition, to maximise the revenue of a geothermal project, Bloomquist [78] and the USAID [100] recommended direct uses of the geothermal fluid after power generation. This configuration is considered as the denominated cascade of geothermal energy application [16].

The proposed geothermal cascade configuration is illustrated in Figure 4. As the three most advanced geothermal prospects are near to Andean indigenous communities dedicated to agriculture business [70], this study proposes two direct uses: greenhouse heating for agricultural crop production, and aquaculture heating for fish farming. A cascade geothermal project might be feasible to develop and maximise the use of the resource in Ecuador. The binary power plant might be combined with aquaculture and greenhouse heating applications (Figure 4). The grouping of electricity generation and direct application not only would supply the demand for electricity and heating, but additionally provide economic development for the communities around the geothermal prospects. 


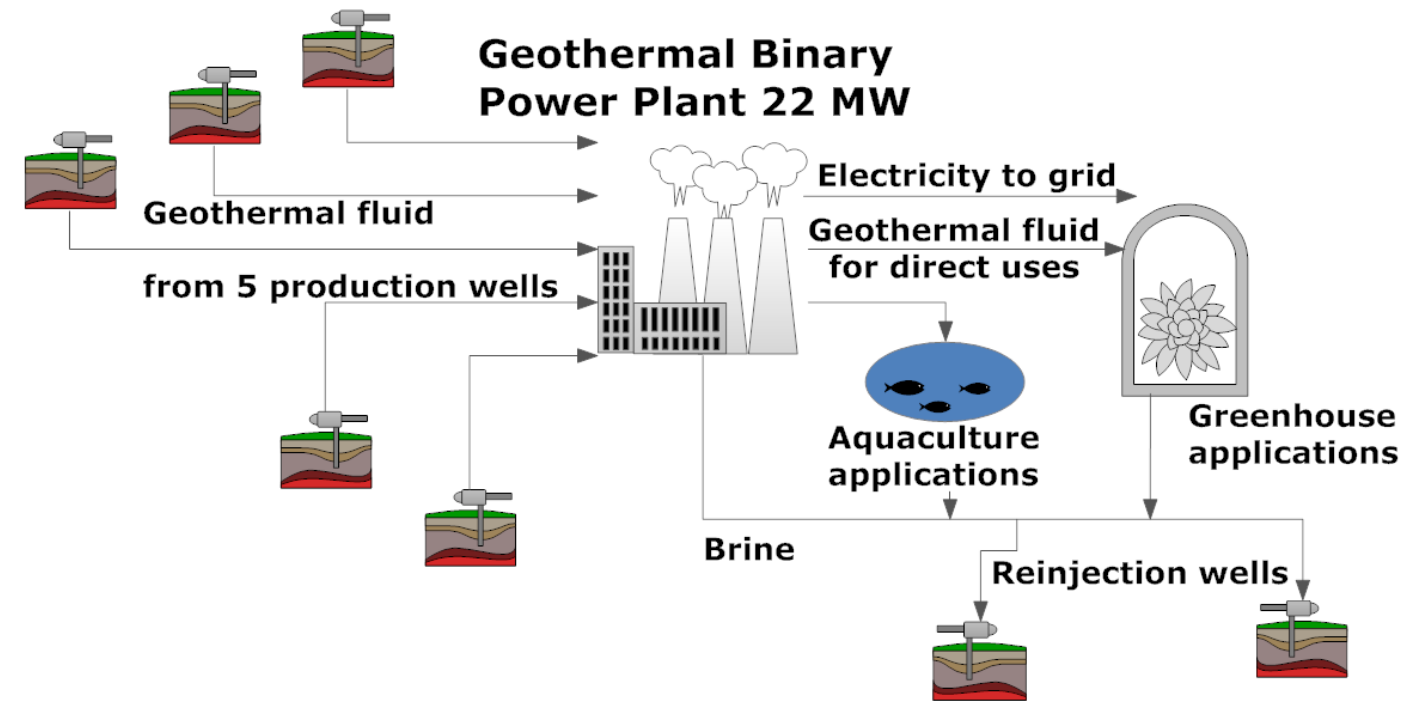

Figure 4: Schematic diagram of the proposed 22 MW Binary geothermal power plant with potential direct applications for aquaculture and greenhouse direct uses.

\subsection{Financial and economic analysis}

Table 6-7 and Figure 5 summarises the financial and economic analyses for direct uses of geothermal heat and the three studied scenarios. The total initial cost of the geothermal power plant was calculated to be 110 million USD for the construction of a $22 \mathrm{MW}$ installed capacity. This would mean approximately 5,000 USD per kilowatt $(\mathrm{kW})$, see Table 7. These results are in line with those of previous studies reported in the literature [14, 19, 50, 77, 78]. A similar cost of 3,200 and 4,800 USD/kW was reported in the Kenyan and Ethiopian context, respectively [76]. Further, World Bank [101] reported a total cost of 100 million USD for developing a $28 \mathrm{MW}$ geothermal power plant in Armenia in 2015. These results are in accord with previous studies where geothermal developments characteristically require an investment of 4,000-5,000 USD/kW [102], 2500-5000 USD $/ \mathrm{kW}$ [28] or $6300 \mathrm{USD} / \mathrm{kW}$ [103]. Thus, the total initial cost of the proposed power plant in Ecuador is comparable to the developmental costs report in the literature.

Table 6: Investment and operation costs for the direct uses of geothermal heat proposed in this study [100].

\begin{tabular}{lrl}
\hline \multicolumn{3}{c}{ GREENHOUSE HEATING } \\
\hline Capital & 312.5 & $\mathrm{USD} / \mathrm{kW}$ \\
Cost of energy & 0.89 & $\mathrm{Ctv} / \mathrm{kWh}$ \\
Operation and Maintenance & 2.75 & $\mathrm{USD}$ \\
Capacity factor & 0.48 \\
\multicolumn{3}{c}{ AQUACULTURE HEATING } \\
Capital & 250 & $\mathrm{USD} / \mathrm{kW}$ \\
Cost of energy & 0.61 & $\mathrm{Ctv} / \mathrm{kWh}$ \\
\hline
\end{tabular}




\begin{tabular}{lll} 
Operation and Maintenance & 2.25 & USD \\
Capacity factor & 0.56 & \\
\hline
\end{tabular}

According to the cost model, power plant construction accounted $50.2 \%$ of the total cost and was the largest cost incurred in the development of the project (Table 7). The second largest cost was the engineering and well field development and accounted $30.6 \%$ of the total initial cost, which includes the exploration drilling stage. Finally, the combination of feasibility study (3.9\%), the permits and approvals of the development $(0.7 \%)$ and the balance of system and miscellaneous (14.6\%) accounted $19.2 \%$ of the total initial cost of the power plant (Table 7). It should be noted that these costs do not include the costs of the suggested direct applications. These results are consistent with Gehringer and Loksha [16] who reported that the cost for engineering and well field development are between $32 \%$ and $42 \%$. However, power plant construction costs of $34 \%$ and $36 \%$ of the total cost reported in the above study [16] were lower than the costs obtained in the present study (Table 7).

Table 7. Total initial costs and annual costs of geothermal power plant obtained by using the RETScreen cost analysis model.

\begin{tabular}{|c|c|c|c|}
\hline \multicolumn{3}{|c|}{ Initial costs (credits) } & \multirow{2}{*}{$\begin{array}{c}\begin{array}{c}\text { Relative } \\
\text { cost }\end{array} \\
3.9 \%\end{array}$} \\
\hline Feasibility & $4,500,000$ & USD & \\
\hline Development & 750,000 & USD & $0.7 \%$ \\
\hline $\begin{array}{l}\text { Engineering, and well field } \\
\text { development }\end{array}$ & $35,000,000$ & USD & $30.6 \%$ \\
\hline Power system & $57,375,011$ & USD & $50.2 \%$ \\
\hline \multicolumn{3}{|l|}{ miscellaneous } & $14.6 \%$ \\
\hline Construction & 12 & $\%$ & \\
\hline Contingencies & $11,715,001$ & USD & \\
\hline Interest during & 18 & Months & \\
\hline $\begin{array}{l}\text { construction }(6 \%)- \\
\text { Period }\end{array}$ & $4,920,301$ & USD & \\
\hline Subtotal & $114,260,313$ & USD & $100 \%$ \\
\hline \multicolumn{4}{|c|}{ Annual costs - Operation and Maintenance } \\
\hline Parts \& labour & 344,988 & USD & \\
\hline $\begin{array}{l}\text { Well field and reservoir } \\
\text { management, community benefits } \\
\text { and overhaul }\end{array}$ & $1,613,129$ & USD & \\
\hline Annual Contingencies & 6.5 & $\%$ & \\
\hline Subtotal & $2,085,618$ & USD & \\
\hline
\end{tabular}

With respect to the annual costs, the operation and maintenance of the power plant was analysed based on three individual costs: parts and labour (344,988 USD), well field (1.6 million USD) and contingencies (127,501 USD). Of the total cost of 201,000 USD, highest costs were 
associated with the electric and control systems (64,500 USD) followed by cooling water and chemicals (70,500 USD), spare parts for the turbine-generator system (37,500 USD), auxiliary systems (19,500 USD) and the cooling system (9,000 USD). These data have been compared with similar studies across the world [76-78, 87]. Labour cost has considered wages and salaries in the Ecuadorian context [87]. The annual labour costs take into account the operating labour of 11 staff: a plant manager (27,696 USD), eight plant operators (94,656 USD), a mechanic (11,832 USD) and another labourer (9,804 USD), representing a total of 143,988 USD.

Financial viability for the three studied scenarios is presented in Table 8. In Scenarios I and III, the debt payment was calculated to be 5.36 million USD per year, constant over the debt term. The corresponding value for Scenario II was 7.06 million USD, which is $30 \%$ higher than Scenario I (Table 8). The NPV was positive for all scenarios except for Scenario IIIA, indicating that the project is feasible in financial terms for Scenario I, II and IIIB.

The simple and equity payback periods are a second set of financial indicators to be analysed (Table 8 and Figure 5). The simple payback for Scenario I was 4.9 years with an equity payback of 3.2 years. Therefore, this scenario might be an attractive for investors not only because of the positive NPV, but also due to the short payback period. For Scenario II, although the equity payback increased to 3.7 years, the simple payback remained the same as that of Scenario I. This is because the initial investment does not change. Furthermore, the NPV stays positive. Thus, Scenario II can also be considered as a financially viable project. In the case of Scenario IIIA, the main financial indicator i.e., NPV was negative meaning that the project is financially unattractive. This scenario is unattractive for investor as the simple payback is 15.6 years and equity payback is 16 years in a project of 25 years life. For Scenario IIIB with infusing of 20 million USD government grants and an income of $8.9 \mathrm{USD} / \mathrm{MWh}$ for the sale of heat for direct applications plus two clean development mechanism (CDM) funding, the project became financially attractive (Table 8 ). The NPV was positive and the simple and equity payback were reduced to 9.3 and 5.6 years, respectively (Figure 8). Therefore, it is clear that direct applications, public incentives and clean funding mechanisms are essential for the success of geothermal energy projects.

Table 8: Financial viability for the three studied scenarios obtained by using RETScreen modelling.

\begin{tabular}{rrrrrl}
\hline Financial indicator & $\begin{array}{r}\text { Scenario I } \\
(25 \text { years })\end{array}$ & $\begin{array}{c}\text { Scenario II } \\
(15 \text { years })\end{array}$ & \multicolumn{2}{c}{ Scenario III (25 years) } & Units \\
\hline & & & & Case B & \\
Incentives and grants & $3,000,000$ & $3,000,000$ & $3,000,000$ & $20,000,000$ & USD \\
& 45.7 & 41.7 & 8.0 & 23.8 & $\%$ \\
Pre-tax IRR - equity & 19.3 & 15.6 & 0.8 & 6.4 & $\%$ \\
Pre-tax IRR - assets & & & & & \\
\hline
\end{tabular}




\begin{tabular}{|c|c|c|c|c|c|}
\hline After-tax IRR - equity & 32.6 & 27.8 & 4.5 & 18.3 & $\%$ \\
\hline After-tax IRR - assets & 13.3 & 8.2 & -2.4 & 2.9 & $\%$ \\
\hline Simple payback & 4.9 & 4.9 & 15.6 & 9.3 & Years \\
\hline Equity payback & 3.2 & 3.7 & 16.0 & 5.6 & Years \\
\hline $\begin{array}{l}\text { Net Present Value } \\
\text { (NPV) }\end{array}$ & $62,776,769$ & $35,959,376$ & $-24,831,772$ & $7,870,200$ & USD \\
\hline $\begin{array}{l}\text { Annual life cycle } \\
\text { savings }\end{array}$ & $9,133,920$ & $5,854,509$ & $-3,612,983$ & $1,145,102$ & USD/year \\
\hline $\begin{array}{l}\text { Benefit-Cost (B-C) } \\
\text { ratio }\end{array}$ & 2.37 & 1.79 & 0.46 & 1.17 & \\
\hline Debt service coverage & 4.34 & 3.30 & 1.37 & 1.94 & \\
\hline $\begin{array}{l}\text { Energy production } \\
\text { cost }\end{array}$ & 72.20 & 91.68 & 72.20 & 41.87 & USD/MWh \\
\hline GHG reduction cost & 56 & 36 & 22 & 7 & $\mathrm{USD} / \mathrm{tCO}_{2}$ \\
\hline \multicolumn{6}{|l|}{$\begin{array}{l}\text { Annual costs and debt } \\
\text { payments }\end{array}$} \\
\hline O\&M costs & $2,085,618$ & $2,085,618$ & $2,085,618$ & $2,085,618$ & USD/year \\
\hline $\begin{array}{l}\text { Debt } \\
\text { payments }\end{array}$ & $5,362,296$ & $7,058,735$ & $5,362,926$ & $5,362,926$ & USD/year \\
\hline $\begin{array}{l}\text { Total annual } \\
\text { costs }\end{array}$ & $7,448,543$ & $9,144,352$ & $7,448,543$ & $7,448,543$ & USD/year \\
\hline $\begin{array}{l}\text { Total annual savings } \\
\text { and income }\end{array}$ & $24,699,421$ & $24,699,421$ & $9,217,876$ & $12,221,955$ & USD/year \\
\hline
\end{tabular}




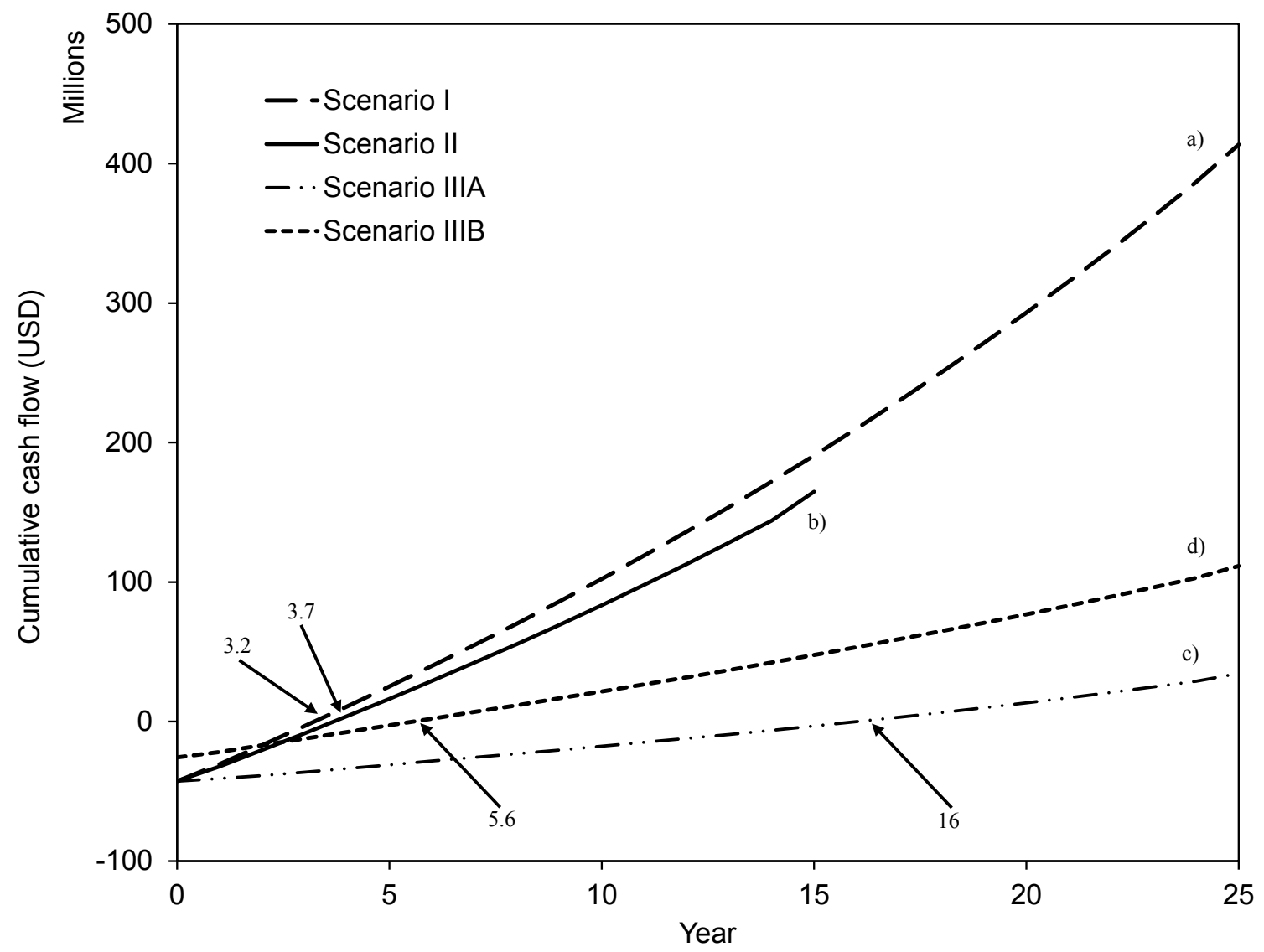

Figure 5: Cumulative cash flow for the three studies scenarios: a) Scenario I, b) Scenario II, c) Scenario IIIA and d) Scenario IIIB

From the microeconomic point of view, the electricity market structure of Ecuador is being supported by different regulations, incentives and policies for promotion of renewable energy. The MEER, MSS (Ministry of Strategic Sectors) and CONELEC have established detailed plans for initial investment of geothermal projects. However, Ecuador lacks a Geothermal Law or dedicated regulations, which presents difficulties for the development of these projects [72]. The results of this study indicates that a $22 \mathrm{MW}$ geothermal power plant in the Chachimbiro prospect would avoid consumption of 486,500 barrels of crude oil per year. This is equivalent to annual savings of 24.3 million USD in oil consumption. It should be cautioned here that these values do not take into account the likely credit generated for reduction of $161,901 \mathrm{tCO}_{2} \mathrm{GHG}$ emissions per year. Therefore, it is clear that geothermal energy could play an important role in the diversification of the Ecuadorian Energy Matrix generating positive impacts on its economy.

From the macro-economic point of view, the share of renewable energy production would be slightly affected by geothermal energy generation due to the large share of hydrothermal electricity. As previously discussed in Section 3.2, 11\% of the electricity mix is covered by interconnections from Colombia and Peru, accounting for 635 MW of installed capacity. 
Additionally, the economic potential of geothermal energy in the country is expected to be 1000 MW. Therefore, geothermal development would be an option to reduce the dependency on external energy supply and is estimated to 40 million USD annually [89, 91, 104].

Another economic impact on the national economy is the possible employment opportunities. It is estimated that approximately 30 workers are required for construction of a $20-50 \mathrm{MW}$ geothermal power plant [76]. Moreover, indirect employment opportunities also increase due to direct applications of geothermal heat in the affected zone. In this study, greenhouse heating and aquaculture were considered as the two likely direct applications of geothermal energy in the prospects, as described in Section 3.1. These developments could possible reduce the incidence of poverty in the communities involved; promote new technologies for greenhouse farming, food processing and fish farming; and improve economy security and reduce greenhouse emissions.

\subsection{Greenhouse emissions}

The results on the GHG emission analysis are presented in Table 9. Based on the current electricity mix in Ecuador (Table 3), more than $184,000 \mathrm{tCO}_{2}$ could be avoided annually if electricity from geothermal resources is exploited. However, if we internalise the losses due to transmission and distribution (12.4\%), approximately 23,000 $\mathrm{tCO}_{2}$ are produced. Therefore, emission analysis of the proposed geothermal project reveals that approximately $161,000 \mathrm{tCO}_{2}$ per year can be avoided. This GHG emission reduction is equivalent to $\mathrm{CO}_{2}$ emissions from 29,000 cars and light trucks or 376,500 barrels of oil, or 15,000 hectares of $\mathrm{CO}_{2}$ sequestration by forests (Table 9).

Table 9: Results of the GHG analysis based on the current energy mix in Ecuador [45].

\begin{tabular}{lrl}
\hline \multicolumn{2}{c}{ GHG emission reduction summary } \\
\hline $\begin{array}{l}\text { Base case GHG emission } \\
\text { Proposed case GHG emission (T\&D }\end{array}$ & $184,818.2$ & $\mathrm{tCO}_{2}$ eq \\
losses) & $22,917.5$ & $\mathrm{tCO}_{2}$ eq \\
$\begin{array}{l}\text { Gross annual GHG emission reduction } \\
\text { (Geothermal project) }\end{array}$ & $161,900.7$ & $\mathrm{tCO}_{2}$ eq \\
& $29,652.0$ & Cars \& light trucks not used \\
Net annual GHG emission reduction is & $376,514.0$ & Barrels of crude oil not consumed \\
equivalent & $14,891.0$ & $\begin{array}{l}\text { Hectares of forest absorbing } \\
\text { carbon }\end{array}$ \\
\hline
\end{tabular}


The feasibility study thus show that Ecuador's commitment to increase the share of renewable energy through the restructuration of its energy matrix can be achieved through investments in geothermal energy. Diversification of the Ecuadorian energy matrix would improve its economy by reducing the fossil fuel electricity consumption and the country's dependence on fossil fuel imports. Thus, the new energy gap, as a result of the change of the productivity matrix, could be filled with electricity produced from geothermal power. With $3000 \mathrm{MW}_{\mathrm{e}}$ of total geothermal potential, Ecuador can explore the use of geothermal resources for direct heat applications and power generation. The technical and economic analyses showed that the produced electric energy and direct use of thermal energy from geothermal resources in the Ecuadorian context can diversify its Energy Matrix and support the energy challenges in the coming years. Geothermal energy harvesting might not only reduce the consumption of fossil fuels, reducing the environmental electricity production impact, but could also create new opportunities of research, employment and positive economic impacts in Ecuadorian society. Although the current electricity framework in Ecuador supports the development of this kind of renewable energy project, the lack of a specific Geothermal Law is the main obstacle to achieve the geothermal target in the country.

\section{Conclusion}

In this study, technical, financial and economic analysis of the development of geothermal energy projects in the Ecuadorian context was carried out. The technical feasibility analysis showed that the binary geothermal power cycle was the most suitable technology to produce electricity in the Chachimbiro prospect according with the estimated temperatures established in PUGR-E. This finding could also be applied to Chacana and Chalpatan prospects. However, the financial analysis would vary highly depending on drilling depth of each project. Aquaculture and greenhouse heating were identified as the most likely applications in the industrial activities within the involved communities. The financial analysis revealed that the investment cost for $1 \mathrm{MW}$ geothermal power plant would be 5.2 million USD installed capacity. Field development and construction accounted for $80 \%$ of the total investment of the power plant. The economic analyses revealed a possible annual saving of 24.3 million USD due to substitution of fossil fuel use for electricity generation. Furthermore, $187 \mathrm{MWh}$ of per year electricity imports from neighbouring countries could also be avoided. Greenhouse gas emissions analyses indicated 162,000 tCO2 eq. could be avoided annually with the proposed project. Direct application of the geothermal heat, after being used for electricity generation, would also increase the socio-economic benefits in the communities involved. The results show that RETScreen is a potent tool to analyse the prefeasibility of geothermal projects under specific considerations. Future research might consider a different model to estimate the drilling cost and then, provide a more accurate financial analysis. 


\section{Acknowledgements}

The authors would like to thank the Ecuadorian Secretariat for Higher Education, Science, Technology and Innovation (SENESCYT- Secretaría de Educación Superior, Ciencia, Tecnología e Innovación) for funding the research visit of Mr Diego Moya at Griffith University and his PhD studies at Imperial College London, Award No. CZ03-35-2017. The Universidad Técnica de Ambato is greatly acknowledged for supporting Mr Diego Moya in his $\mathrm{PhD}$ studies, Resolución No. 1895-CU-P-2017. Dr Angel Pérez-Navarro, Senior Researcher of the Universidad de Valencia, Spain, is also acknowledged for his valuable comments and suggestions rendered during the preparation of the manuscript. CELEC-EP is also acknowledged for providing the Plan for the Utilization of Geothermal Resources in Ecuador. Ms Andrea Morales, Ms Pauline Frasser, Ms Christa Gerard and Ms Jacqui Posener at Griffith University are acknowledged for their support in proof reading the manuscript.

\section{References}

[1] The United Nations Framework Convention on Climate Change. (1992, 25 May). Background on the UNFCCC: The international response to climate change. Available: http://unfccc.int/essential_background/items/6031.php

[2] M. Hulme, "1.5 centigrades degrees and climate research after the Paris Agreement," Nature Climate Change, vol. Advance online publication, 02/01/online 2016.

[3] M. F. Akorede, H. Hizam, M. Z. A. Ab Kadir, I. Aris, and S. D. Buba, "Mitigating the anthropogenic global warming in the electric power industry," Renewable and Sustainable Energy Reviews, vol. 16, pp. 2747-2761, June 2012.

[4] N. Heidari and J. M. Pearce, "A review of greenhouse gas emission liabilities as the value of renewable energy for mitigating lawsuits for climate change related damages," Renewable and Sustainable Energy Reviews, vol. 55, pp. 899-908, 2016/03/01/ 2016.

[5] G. B. Upton and B. F. Snyder, "Funding renewable energy: An analysis of renewable portfolio standards," Energy Economics, vol. 66, pp. 205-216, 2017/08/01/ 2017.

[6] D. Moya, C. Aldás, G. López, and P. Kaparaju, "Municipal solid waste as a valuable renewable energy resource: a worldwide opportunity of energy recovery by using Waste-To-Energy Technologies," Energy Procedia, vol. 134, pp. 286-295, 2017/10/01/ 2017.

[7] International Energy Agency - IEA. (2017, 20 November). Key world energy statistics 2017. Available: https://www.iea.org/publications/freepublications/publication/KeyWorld2017.pdf

[8] P. Moriarty and D. Honnery, "What is the global potential for renewable energy?," Renewable and Sustainable Energy Reviews, vol. 16, pp. 244-252, 1// 2012.

[9] P. Moriarty and S. J. Wang, "Assessing Global Renewable Energy Forecasts," Energy Procedia, vol. 75, pp. 2523-2528, 2015/08/01/2015.

[10] D. Moya, C. Aldás, D. Jaramillo, E. Játiva, and P. Kaparaju, "Waste-To-Energy Technologies: an opportunity of energy recovery from Municipal Solid Waste, using Quito - Ecuador as case study," Energy Procedia, vol. 134, pp. 327-336, 2017/10/01/ 2017.

[11] D. Moya, R. Torres, and S. Stegen, "Analysis of the Ecuadorian energy audit practices: A review of energy efficiency promotion," Renewable and Sustainable Energy Reviews, vol. 62, pp. 289296, 2016/09/01/ 2016.

[12] UNFCCC. (2015, April 7). Ecuador's Intended Nationally Determined Contribution (INDC). Available:

http://www4.unfccc.int/submissions/INDC/Published\%20Documents/Ecuador/1/Ecuador\%20IN DC\%2001-10-2015\%20-\%20english\%20unofficial\%20translation.pdf 
[13] UNFCCC. (2015, April 7). Ecuador Submits its Climate Action Plan Ahead of 2015 Paris Agreement. Available: http://newsroom.unfccc.int/unfccc-newsroom/ecuador-submits-itsclimate-action-plan-ahead-of-2015-paris-agreement/

[14] M. Hillesheim and G. Mosey. (2013, 15 June). Feasibility Study of Economics and Performance of Geothermal Power Generation at the Lakeview Uranium Mill Site in Lakeview, Oregon. Available: http://www.nrel.gov/docs/fy14osti/60251.pdf

[15] P. Sanchez-Alfaro, G. Sielfeld, B. V. Campen, P. Dobson, V. Fuentes, A. Reed, et al., "Geothermal barriers, policies and economics in Chile - Lessons for the Andes," Renewable and Sustainable Energy Reviews, vol. 51, pp. 1390-1401, November 2015.

[16] M. Gehringer and V. Loksha, "Geothermal handbook: planning and financing power generation. Energy Sector Management Assistance Program (ESMAP)," ed: The International Bank for Reconstruction and Development, The World Bank Group, Washington DC, United States, Energy Sector Management Assistance Program technical report 02/12, 164 pp., 2012, p. 164.

[17] B. Steingrímsson, "Phases of geothermal development in Iceland: from a hot spring to utilization," 2014.

[18] Y. Kalinci, A. Hepbasli, and I. Dincer, "Techno-economic analysis of a stand-alone hybrid renewable energy system with hydrogen production and storage options," International Journal of Hydrogen Energy, vol. 40, pp. 7652-7664, June 292015.

[19] G. Cavazzini and P. Dal Toso, "Techno-economic feasibility study of the integration of a commercial small-scale ORC in a real case study," Energy Conversion and Management, vol. 99, pp. 161-175, July 152015.

[20] M. Astolfi, M. C. Romano, P. Bombarda, and E. Macchi, "Binary ORC (Organic Rankine Cycles) power plants for the exploitation of medium-low temperature geothermal sources - Part B: Techno-economic optimization," Energy, vol. 66, pp. 435-446, January, 32014.

[21] S. Loutatidou and H. A. Arafat, "Techno-economic analysis of MED and RO desalination powered by low-enthalpy geothermal energy," Desalination, vol. 365, pp. 277-292, June 12015.

[22] S. Rahmouni, N. Settou, N. Chennouf, B. Negrou, and M. Houari, "A Technical, Economic and Environmental Analysis of Combining Geothermal Energy with Carbon Sequestration for Hydrogen Production," Energy Procedia, vol. 50, pp. 263-269, 2014.

[23] Y. Bicer and I. Dincer, "Development of a new solar and geothermal based combined system for hydrogen production," Solar Energy, vol. 127, pp. 269-284, April 2016.

[24] O. Hanbury and V. R. Vasquez, "Life cycle analysis of geothermal energy for power and transportation: A stochastic approach," Renewable Energy, vol. 115, pp. 371-381, 2018/01/01/ 2018.

[25] M. Z. Lukawski, B. J. Anderson, C. Augustine, L. E. Capuano Jr, K. F. Beckers, B. Livesay, et al., "Cost analysis of oil, gas, and geothermal well drilling," Journal of Petroleum Science and Engineering, vol. 118, pp. 1-14, 6// 2014.

[26] K. Yost, A. Valentin, and H. H. Einstein, "Estimating cost and time of wellbore drilling for Engineered Geothermal Systems (EGS) - Considering uncertainties," Geothermics, vol. 53, pp. 85-99, January 2015.

[27] M. Astolfi, M. C. Romano, P. Bombarda, and E. Macchi, "Binary ORC (organic Rankine cycles) power plants for the exploitation of medium-low temperature geothermal sources - Part A: Thermodynamic optimization," Energy, vol. 66, pp. 423-434, January, 32014.

[28] D. Budisulistyo and S. Krumdieck, "Thermodynamic and economic analysis for the pre-feasibility study of a binary geothermal power plant," Energy Conversion and Management, vol. 103, pp. 639-649, October 2015.

[29] D. Yildirim and L. Ozgener, "Thermodynamics and exergoeconomic analysis of geothermal power plants," Renewable and Sustainable Energy Reviews, vol. 16, pp. 6438-6454, October 2012.

[30] V. Zare, "A comparative exergoeconomic analysis of different ORC configurations for binary geothermal power plants," Energy Conversion and Management, vol. 105, pp. 127-138, November 152015. 
[31] S. Ghafghazi, T. Sowlati, S. Sokhansanj, and S. Melin, "Techno-economic analysis of renewable energy source options for a district heating project," International Journal of Energy Research, vol. 34, pp. 1109-1120, 2010.

[32] F. Calise, M. D. d'Accadia, A. Macaluso, A. Piacentino, and L. Vanoli, "Exergetic and exergoeconomic analysis of a novel hybrid solar-geothermal polygeneration system producing energy and water," Energy Conversion and Management, vol. 115, pp. 200-220, January 52016.

[33] E. Trumpy, S. Botteghi, F. Caiozzi, A. Donato, G. Gola, D. Montanari, et al., "Geothermal potential assessment for a low carbon strategy: A new systematic approach applied in southern Italy," Energy, vol. 103, pp. 167-181, 5/15/ 2016.

[34] C. Yilmaz, M. Kanoglu, and A. Abusoglu, "Thermoeconomic cost evaluation of hydrogen production driven by binary geothermal power plant," Geothermics, vol. 57, pp. 18-25, September 2015.

[35] C. Zhou, "Hybridisation of solar and geothermal energy in both subcritical and supercritical Organic Rankine Cycles," Energy Conversion and Management, vol. 81, pp. 72-82, May 2014.

[36] M. Mehrpooya, H. Hemmatabady, and M. H. Ahmadi, "Optimization of performance of Combined Solar Collector-Geothermal Heat Pump Systems to supply thermal load needed for heating greenhouses," Energy Conversion and Management, vol. 97, pp. 382-392, June 2015.

[37] C. Yilmaz, M. Kanoglu, and A. Abusoglu, "Exergetic cost evaluation of hydrogen production powered by combined flash-binary geothermal power plant," International Journal of Hydrogen Energy, vol. 40, pp. 14021-14030, October 2015.

[38] C. Yilmaz, M. Kanoglu, A. Bolatturk, and M. Gadalla, "Economics of hydrogen production and liquefaction by geothermal energy," International Journal of Hydrogen Energy, vol. 37, pp. 20582069, January 2012.

[39] A. Hochwimmer, L. Urzua, G. Ussher, and C. Parker, "Key Performance Indicators for Pumped Well Geothermal Power Generation," in World Geothermal Congress - WGC2015, Melbourne, 2015.

[40] F. Molina and J. Martí, "Proposal for an initial development strategy for the Borinquen geothermal zone (Cañas Dulces, Costa Rica)," Renewable Energy, vol. 118, pp. 409-424, 2018/04/01/ 2018.

[41] P. Olasolo, M. C. Juárez, J. Olasolo, M. P. Morales, and D. Valdani, "Economic analysis of Enhanced Geothermal Systems (EGS). A review of software packages for estimating and simulating costs," Applied Thermal Engineering, vol. 104, pp. 647-658, July 52016.

[42] RETScreen, Clean Energy Project Analysis, RETScreen ${ }^{\circledR}$ Engineering \& Cases Textbook, Third Edition ed. Canada: Minister of Natural Resources Canada, 2005.

[43] U. S. D. o. Energy. (2016, 15 June). Geothermal electricity technology evaluation model. Available: http://energy.gov/eere/geothermal/geothermal-electricity-technology-evaluationmodel

[44] S. Sinha and S. S. Chandel, "Review of software tools for hybrid renewable energy systems," Renewable and Sustainable Energy Reviews, vol. 32, pp. 192-205, April 2014.

[45] RETScreen. (2014, 29 September). RETScreen Clean Energy Project Analysis software. Available: http://www.retscreen.net/de/home.php

[46] K.-H. Lee, D.-W. Lee, N.-C. Baek, H.-M. Kwon, and C.-J. Lee, "Preliminary determination of optimal size for renewable energy resources in buildings using RETScreen," Energy, vol. 47, pp. 83-96, November 2012.

[47] G. J. Leng, "RETScreen ${ }^{\mathrm{TM}}$ international: a decision support and capacity building tool for assessing potential renewable energy projects," Industry and environment-Paris-, vol. 23, pp. 2223,2000 .

[48] A. H. Mirzahosseini and T. Taheri, "Environmental, technical and financial feasibility study of solar power plants by RETScreen, according to the targeting of energy subsidies in Iran," Renewable and Sustainable Energy Reviews, vol. 16, pp. 2806-2811, June 2012.

[49] S. Stevanović and M. Pucar, "Financial measures Serbia should offer for solar water heating systems," Energy and Buildings, vol. 54, pp. 519-526, November 2012. 
[50] A. Khalid and H. Junaidi, "Study of economic viability of photovoltaic electric power for Quetta - Pakistan," Renewable Energy, vol. 50, pp. 253-258, February 2013.

[51] A. M. Paudel and H. Sarper, "Economic analysis of a grid-connected commercial photovoltaic system at Colorado State University-Pueblo," Energy, vol. 52, pp. 289-296, April 2013.

[52] N. Caglayan, C. Ertekin, and F. Evrendilek, "Spatial viability analysis of grid-connected photovoltaic power systems for Turkey," International Journal of Electrical Power \& Energy Systems, vol. 56, pp. 270-278, March 2014.

[53] A. M. Fathoni, N. A. Utama, and M. A. Kristianto, "A Technical and Economic Potential of Solar Energy Application with Feed-in Tariff Policy in Indonesia," Procedia Environmental Sciences, vol. 20, pp. 89-96, 2014.

[54] A. Gupta, A. Cemesova, C. J. Hopfe, Y. Rezgui, and T. Sweet, "A conceptual framework to support solar PV simulation using an open-BIM data exchange standard," Automation in Construction, vol. 37, pp. 166-181, January 2014.

[55] P. Peerapong and B. Limmeechokchai, "Investment Incentive of Grid Connected Solar Photovoltaic Power Plant under Proposed Feed-in Tariffs Framework in Thailand," Energy Procedia, vol. 52, pp. 179-189, 2014.

[56] K. Y. Kebede, "Viability study of grid-connected solar PV system in Ethiopia," Sustainable Energy Technologies and Assessments, vol. 10, pp. 63-70, June 2015.

[57] Y. Himri, S. Rehman, A. Agus Setiawan, and S. Himri, "Wind energy for rural areas of Algeria," Renewable and Sustainable Energy Reviews, vol. 16, pp. 2381-2385, June 2012.

[58] T. Hong, C. Koo, and T. Kwak, "Framework for the implementation of a new renewable energy system in an educational facility," Applied Energy, vol. 103, pp. 539-551, March 2013.

[59] E. E. Nordman, "Energy transitions in Kenya's tea sector: A wind energy assessment," Renewable Energy, vol. 68, pp. 505-514, August 2014.

[60] O. Nematollahi, H. Hoghooghi, M. Rasti, and A. Sedaghat, "Energy demands and renewable energy resources in the Middle East," Renewable and Sustainable Energy Reviews, vol. 54, pp. 1172-1181, February 2016.

[61] L. Kosnik, "The potential for small scale hydropower development in the US," Energy Policy, vol. 38, pp. 5512-5519, October 2010.

[62] C. J. Sandt and M. W. Doyle, "The hydrologic and economic feasibility of micro hydropower upfitting and integration of existing low-head dams in the United States," Energy Policy, vol. 63, pp. 261-271, December 2013.

[63] C. R. Chamorro, M. E. Mondéjar, R. Ramos, J. J. Segovia, M. C. Martín, and M. A. Villamañán, "World geothermal power production status: Energy, environmental and economic study of high enthalpy technologies," Energy, vol. 42, pp. 10-18, 6// 2012.

[64] A. Hidalgo, L. Villacrés, R. Hechavarría, and D. Moya, "Proposed integration of a photovoltaic solar energy system and energy efficient technologies in the lighting system of the UTA-Ecuador," Energy Procedia, vol. 134, pp. 296-305, 2017/10/01/ 2017.

[65] E. Albornoz. (2013, May, 6 ). The new Ecuador's electric sector (El nuevo sector eléctrico ecuatoriano). Available: http://www.energia.gob.ec/wp-content/plugins/downloadmonitor/download.php?id $=473 \&$ force $=0$

[66] SENPLADES. (2012, 6 April). National Plan of Well Living (Plan Nacional del Buen Vivir). Available: content/uploads/downloads/2012/07/Plan_Nacional_para_el_Buen_Vivir.pdf

[67] R. Correa, J. Glas, R. Poveda, E. Albornoz, S. Ruiz, P. Muñoz, et al. (2012, 6 May). Master Plan of Electrification (Plan Maestro de Electrifiaccion) - Study and management of electricity demand (Estudio y gestión de la demanda eléctrica). Available: http://www.conelec.gob.ec/archivos_articulo/doc_10329_doc_10329_PME_20132022_Vol2_Estudio_y_gestion_de_- la_demanda_electrica.zip 
[68] SENPLADES. (2012, 20 September). Transformation of the Productive Matrix (Transformación de la Matriz Productiva). Available: http:/www.planificacion.gob.ec/wpcontent/uploads/downloads/2013/01/matriz_productiva_WEBtodo.pdf

[69] B. Beate and M. Urquizo, "Geothermal Country Update for Ecuador: 2010 - 2015 " Proceedings World Geothermal Congress 20152015.

[70] A. Lloret and J. Labus, "Geothermal development in Ecuador: history, current status and future," Geothermal training programme, vol. 1, pp. 1-11, March 23, 20142014.

[71] B. Beate, "Plan for the utilization of geothermal resources in Ecuador (Plan para el aprovechamiento de los recursos geotérmicos en el Ecuador)," vol. 1, Ministry of Electricity and Renewable Energy (Ministerio de Electricidad y Energía Renovable), Ed., ed. Quito - Ecuador: MEER, 2010, pp. 1-177.

[72] D. Moya and P. Kaparaju, "Obstacles and strategies of achieving geothermal energy target of 1000 MW in Ecuador: a techno-political overview," in 37th New Zealand Geothermal Workshop, Taupo, New Zealand, 2015.

[73] G. Oliveros and M. Urquizo. (2014, 13 May). Current state of geothermal in Ecuador and Colombia (Estado actual de la Geotermia en Ecuador y Colombia). Available: https://www.google.com.au/url? sa=t\&rct=j\&q=\&esrc=s\&source=web\&cd=8\&cad=rja\&uact=8\& ved $=0 \mathrm{CFQQFjAH \& url=http} \% 3 \mathrm{~A} \% 2 \mathrm{~F} \% 2$ Falcuenet.eu $\% 2 \mathrm{Fdms}-$

files.php\%3Faction\%3Ddoc\%26id\%3D686\&ei=-

ulLVe7bGeLOmwWC5IEg\&usg=AFQjCNH9ogy88LkY2pQUcP6fi7v1lDeJGg\&bvm=bv.9276 5956,d.dGY

[74] RETScreen. (2005, 29 July). Clean Energy Project Analysis: RETScreen Engineering \& Cases. Available: www.retscreen.net/download.php/ang/1016/0/Textbook.pdf

[75] G. Bloomquist, "Short course: Reducing Drilling Risk - From Exploration to Field Management; Module: Risk Mitigation Revisited.," in World Geothermal Congress 2015, Melbourne, Australia, 2015 .

[76] G. Bloomquist, "Updated costs of geothermal development," D. Moya, Ed., ed. Brisbane, Australia, 2015.

[77] G. Bloomquist, J. Ponsness, and C. Roos. (2009, 8 July). Introduction to Financial Modeling Considerations. Available: http://www.partnershipinternational.com/Proceedings/9.1\%20\%20COURSE\%20ON\%20OF\%20GEOTHERMAL\%20E CONOMIC\%20EVALUATION\%20\&\%20MODELING,\%20Gordon\%20Bloomquist,\%20Jeff\% 20Ponsness, \%20EnSight\%20and\%20WSU.pdf

[78] G. Bloomquist. (2009, 8 July). Economics and Financing of Geothermal Projects. Available: http://northwestchptap.org/ResourcesSoftwareLinks/Software.aspx

[79] L. Torres and M. Urquizo. (2013, 13 May). Evaluation of the initial pre-feasibility study of the geothermal project Chachimbiro (Ecuador) (Evaluación del estudio de prefactibilidad inicial del proyecto geotérmico Chachimbiro (Ecuador)). Available: http://www.ndf.fi/sites/ndf.fi/files/news_attach/libro_resumen_diplomado_2013.pdf

[80] E. Aguilera. (2010, 14 May). Geothermal Energy in Ecuador: a roadmap for sustainable development (Geotermia en el Ecuador: una hoja de ruta para su desarrollo sustentable) Available: http://noticias.espe.edu.ec/eaguilera/files/2012/06/Documento_Taller_Ibarra__Final11.pdf

[81] R. DiPippo, Geothermal power plants: principles, applications, case studies and environmental impact (3rd Edition): Butterworth-Heinemann, 2012.

[82] A. Shulyupin and A. Chermoshentseva, "Maximum Flow-Rate of Steam-Water Wells," Proceedings World Geothermal Congress 2015, 2015.

[83] P. Valdimarsson, "Short course: Electricity Generation from Low Temperature Geothermal Resources," in World Geothermal Congress 2015, Melbourne, Australia, 2015.

[84] M. H. Dickson and M. Fanelli, Geothermal energy: utilization and technology. Sterling, VA; London: Earthscan, 2005. 
[85] CONELEC, "Statistical Bulletin of the Ecuadorian electricity sector, 2011 (Boletín estadístico del sector eléctrico ecuatoriano, 2011)," Electrical National Council, Ed., ed. Quito, Ecuador, 2012, p. 189.

[86] CONELEC. (2011, 6 September). Feed in Tariffs regulation No. CONELEC - 004/11 (REGULACION No. CONELEC - 004/11). Available: http://www.windworks.org/cms/uploads/media/CONELEC_004-11_ERNC.pdf

[87] R. Espinosa, "Unified scale of monthly salaries of Ecuador (Escala de remuneraciones mensuales unificadas del Ecuador)," M. o. L. R. M. d. R. Laborales), Ed., ed. Quito, Ecuador: Ministry of Labour Relations (Ministerio de Relaciones Laborales), 2012.

[88] B. Rickard. (2012, 27 May). Drilling and testing geothermal wells. Available: http://www.esmap.org/sites/esmap.org/files/Bailey_Exploration\%28Day1\%29_0.pdf

[89] CONELEC. (2015, 7 May). National Balance of Electric Power (Balance Nacional de Energía Eléctrica). Available: http://www.conelec.gob.ec/contenido.php?cd=10261\&l=1

[90] V. Orejuela. (2014, 15 September). Outlook for the electricity energy matrix in Ecuador(Perspectivas de la matriz energética de electricidad en el Ecuador).

[91] CONELEC. (2012, 6 May). Institutional Strategic Plan 2013-2016 of the National Electricity Council (CONELEC) (Plan estratégico institucional 2013-2016 del Consejo Nacional de Electricidad). Available: http://www.conelec.gob.ec/images/documentos/doc_10564_Plan\%20Estrat\%C3\%A9gico\%20Co nelec\%202013-2016.pdf

[92] A. Cormier and V. Bellassen, "The risks of CDM projects: How did only $30 \%$ of expected credits come through?," Energy Policy, vol. 54, pp. 173-183, March 2013.

[93] V. Stefansson, "World Geothermal Assessment," in Proceedings of the World Geothermal Congress, Turkey, 2005, pp. 24-29.

[94] E. Almeida, G. Sandoval, C. Panichi, P. Noto, and L. Bellucci. (1990, 31 May). Geothermal investigations with isotope and geochemical techniques in Latin America - Modelo geotérmico preliminar de áreas volcánicas del Ecuador a partir de estudios químicos e isotópicos de manifestaciones termales. Available: http://wwwnaweb.iaea.org/napc/ih/documents/TECDOCS/TECDOC\%200641\%20Geothermal\%20Latin\%2 0America\%201993\%20.pdf

[95] B. Beate and R. Salgado, "Geothermal Country Update for Ecuador: 2005 - 2010," Proceedings World Geothermal Congress 2010, 2010.

[96] M. S. Haddad, "Capacity choice and water management in hydroelectricity systems," Energy Economics, vol. 33, pp. 168-177, March 2011.

[97] S. Sultana and Z. Chen, "Modeling flood induced interdependencies among hydroelectricity generating infrastructures," Journal of Environmental Management, vol. 90, pp. 3272-3282, August 2009.

[98] I. Herath, M. Deurer, D. Horne, R. Singh, and B. Clothier, "The water footprint of hydroelectricity: a methodological comparison from a case study in New Zealand," Journal of Cleaner Production, vol. 19, pp. 1582-1589, September 2011.

[99] E. Aguilera, R. Cioni, F. Gherardi, G. Magro, L. Marini, and Z. Pang, "Chemical and isotope characteristics of the Chachimbiro geothermal fluids (Ecuador)," Geothermics, vol. 34, pp. 495$517,8 / / 2005$.

[100] USAID. (2013, 29 May). Geothermal Direct-Use Guidebook - A case study for Kenya. Available: http://www.idd.landolakes.com/getattachment/Resources/Publications/PAA-Direct-UseGuidebook/PAA-Direct-Use-Guidebook.pdf.aspx

[101] World Bank. (2015, 22 June). World Bank Supports Exploration of Geothermal Resources in Armenia. Available: http://www.worldbank.org/en/news/press-release/2015/06/08/world-banksupports-exploration-of-geothermal-resources-in-armenia

[102] P. Meier, M. Vagliasindi, M. Imran, A. Eberhard, and T. Siyambalapitiya. (2015, 22 June). The Design and Sustainability of Renewable Energy Incentives: An Economic Analysis. Available: 
https://openknowledge.worldbank.org/bitstream/handle/10986/20524/922240PUB0978100Box3 85358B00PUBLIC0.pdf? sequence $=1$

[103] A. Colmenar-Santos, M. Folch-Calvo, E. Rosales-Asensio, and D. Borge-Diez, "The geothermal potential in Spain," Renewable and Sustainable Energy Reviews, vol. 56, pp. 865-886, April 2016.

[104] CONELEC. (2008, 6 September). Statistics of the Ecuadorian Electricity Sector, 2008 (Estadística del sector Eléctrico Ecuatoriano). Available: http://www.conelec.gob.ec/images/documentos/Boletin2008.pdf 